\title{
Disengaged, Positive, or Negative: Parents' Attitudes Toward Learning From Home Amid COVID-19 Pandemic
}

\author{
Ahmad R. Pratama $\mathbb{D}^{1} \cdot$ Firman M. Firmansyah $\mathbb{1}^{2}$ \\ Accepted: 6 May 2021 / Published online: 21 May 2021 \\ (C) The Author(s), under exclusive licence to Springer Science+Business Media, LLC, part of Springer Nature 2021
}

\begin{abstract}
The COVID-19 pandemic has forced many countries to close their schools and to change their education system to adopt the learning from home (LFH) method, which arguably requires more direct involvement from parents to succeed. This study explored parent's attitudes toward LFH policy based on a survey of 261 participants from 16 provinces in Indonesia. Employing latent class analysis, we revealed three distinct groups of parents with unique compounds of attitudes toward LFH (i.e., disengaged, positive, and negative). Disengaged parents neither consider LFH useful, nor do they see it as demanding. In contrast, the other two groups of parents have quite the opposite views on the usefulness and demandingness of LFH. Further analysis using multinomial logistic regression revealed that older parents from low-income households tend to be disengaged while fathers of young children tend to have negative attitudes toward LFH. Interestingly, the ownership of a personal computer at home seems to be a key indicator of parents with positive attitudes toward LFH after controlling for other demographic factors. How the findings provide a firsthand insight on the existence of digital divide by highlighting the importance of access to personal computers at home is further discussed.
\end{abstract}

Keywords COVID-19 $\cdot$ Learning from home $\cdot$ Parents $\cdot$ Attitudes $\cdot$ Digital divide $\cdot$ Personal computers

\section{Highlights}

- Three groups of parents based on their attitudes toward the learning from home (LFH) policy amid COVID-19 pandemic were disengaged, positive, and negative.

- Disengaged parents did not consider LFH useful, nor did they see it as demanding.

- Parents with positive attitudes toward LFH considered it useful and not demanding, contrary to the other group of parents with negative attitudes who found it very demanding and not that useful.

- Older parents from low-income households tended to be disengaged while fathers of young children tended to have negative attitudes toward LFH.

- The ownership of a personal computer at home was a key indicator of parents with positive attitudes toward LFH after controlling for demographic factors.

Supplementary information The online version contains supplementary material available at https://doi.org/10.1007/s10826021-01982-8.

Ahmad R. Pratama

ahmad.rafie@uii.ac.id

1 Department of Informatics, Universitas Islam Indonesia, Jl. Kaliurang KM. 14,5, Sleman, DI Yogyakarta 55241, Indonesia

2 Department of Technology and Society, Stony Brook University, 100 Nicolls Rd, Stony Brook, NY 11794, USA
The onset of Coronavirus Disease 2019 (COVID-19) globally in the first quarter of 2020 has forced many countries to close their schools and to change their education system to adopt the learning from home (LFH) method as an effort to help flatten the pandemic curve. With the ministerial order signed on March 24, 2020, Indonesia decided to implement the LFH policy nationwide, especially for the K-12 education (Kementerian Pendidikan dan Kebudayaan, 2020a). The Indonesian government also pointed out three different scenarios for when the LFH should end, with one of them by the end of 2020 (CNN Indonesia, 2020). However, a spike in COVID-19 cases in early 2021 has compelled some 
authorities to extend the policy to an even longer period (Azmi, 2021; Office of Assistant to Deputy Cabinet Secretary for State Documents and Translation, 2021).

At the center of the LFH policy is distance learning, especially online learning. Ideally, it should involve in-person online interaction between teachers and their students on a regular basis, relying on digital forms of synchronous and asynchronous communication such as emails, instant messaging apps, discussion boards, video calls or teleconferences, collaboration tools, and learning management systems. However, many schools, teachers, students, and parents were not ready to make such a sudden and drastic change in teaching and learning methods as the consequences of the LFH policy (Putri et al., 2020). Some schools and teachers may not necessarily have what it takes to do online learning, or even any other form of distance learning that does not require the same level of infrastructures and facilitating conditions as online learning (Rasmitadila et al., 2020).

To help cope with that gap, one of the programs introduced by the Indonesian governments was the free-to-air LFH program broadcast by TVRI, the national television broadcasting company, on school days starting on April 13, 2020 (Kementerian Pendidikan dan Kebudayaan, 2020b). However, due to limited time slots available and the need for accommodating all education levels, the program is only available for thirty minutes a day for every three grades i.e., $1^{\text {st }}-3^{\text {rd }}$ graders, $4^{\text {th }}-6^{\text {th }}$ graders (elementary school), $7^{\text {th }}-9^{\text {th }}$ graders (junior high school), and $10^{\text {th }}-12^{\text {th }}$ graders (senior high school). Considering that fact, this program is meant to be a complement rather than a substitute for the in-class instruction or any other learning strategies that each school adopted. Furthermore, teachers are no longer able to provide the same level of guidance, supervision, and monitoring in distance learning the way they do in class settings that was the normal prior to COVID-19 pandemic. This situation makes parent involvement -parents' participation in the educational process of their children (Fishel and Ramirez, 2005)- an important key in the LFH policy for it to succeed, especially for children in the preschool or elementary school age who are presumably less independent than secondary school students.

\section{Learning From Home}

The term "learning from home" (LFH) in this study is directly translated from the Indonesian term of "belajar dari rumah" (BDR) that is officially used by the Indonesian government to refer to such a policy amid COVID-19 pandemic (Kementerian Pendidikan dan Kebudayaan, 2020a, 2020b, 2020c). This policy encourages schools and teachers to customize delivery modes based on locally available technology infrastructures, to keep providing the necessary guidance and interactions to the students instead of simply giving them homeworks and assignments to do, and to focus on providing qualitative feedback instead of quantitative feedback (Kementerian Pendidikan dan Kebudayaan, 2020a). It also expects more initiatives from students such as to document their learning activities at home as well as more involvement from parents such as making sure their children follow the teachers' leads and to help them report their LFH sessions through pictures or videos (Kementerian Pendidikan dan Kebudayaan, 2020c). Another term that refers to the same notion is "Learning at Home" that is more commonly used in Australia (Brown et al., 2020; Masters et al., 2020). Given the circumstances and the recency, it is understandable that researchers have yet to come to an agreement on what to call such a new concept. Nonetheless, we decided to use the term LFH in this study since it is also used in some English based popular publications in both Indonesian (Sikirit, 2020) and American contexts (Cross, 2020).

In theoretical concepts, LFH in this study is different from home education or any other similar terms such as home school education, homeschooling, or domestic education. Home education as can be seen in early modern Italy in the sixteenth and seventeenth century (Evangelisti, 2013) reemerged in the late 1960s and early 1970s in the United States as an alternative to institutionalized education (Knowles et al., 1994). Contrary to that, LFH is still part of institutionalized education itself with some changes in the method that it adopts a distance learning approach due to a force majeure, which in this case is COVID-19 pandemic, to replace all in-class learning activities. In that sense, many things remain unchanged; the same curricula still apply and the same teachers still teach the same subjects to the same students. In some cases, the same traditional instruction approach used in the in-class settings is used, albeit with some technical differences due to the use of information and communication technology (ICT) in delivering said instructions to the students (Kementerian Pendidikan dan Kebudayaan, 2020c).

\section{Parent Involvement}

Regardless of its differences from home school education, in which the parents are the teachers to their own children, parent involvement or also known as parent engagement (Gross et al., 2020) in LFH is not something that can be underestimated. Instead, as past studies show (Kellaghan et al., 1993; Topor et al., 2010), parent involvement is arguably one of the key factors that determines the extent to which the program will succeed. In that regard, different ages of children require different parent involvement; younger children such as preschoolers require more directed and extensive parent involvement while older children such as high schoolers may only require light supervision 
(Nye et al., 2006; Eccles \& Harold, 1993). Indeed, family situations, parenting style, and culture would also influence how parents would intervene (Pena, 2000). For example, in Indonesia, less educated parents were less involved in their children's education compared to more educated parents, due to lack of educational capability and resources, and less flexible working hours (Yulianti et al., 2019).

Even though some consider the parent involvement in children's education amid the pandemic as something that parents have never done before, in fact this practice, we argue, is still related to parent involvement that has been around for decades (see Fishel \& Ramirez, 2005 for review). In the more casual settings, such as in the prepandemic, parent involvement is commonly found in a form of homework assistance. For instance, some parents will remind their children to finish their homework or even help them solve difficult problems like math (Pezdek et al., 2002). One main difference between parent involvement in the past and nowadays is amid the abundance of advanced learning technology tools today, not all parents have the technological skills such as the abilities to use and navigate learning management systems, to curate materials from open education resources, and to utilize video conferencing apps that are necessary for such involvement in this new age. Thus, parents who are more educated, digitally literate, and own ICT devices are already in an advantaged position (Clark et al. 2005; Plowman et al., 2011).

\section{Social Inequality and Digital Divide}

The fact that some parents are in the already advantaged position means there are some others in the disadvantaged position. A number of research studies in both developed and developing countries have investigated the relationships between social inequality and digital divide, a gap that makes those who own ICT devices be able to access more information than others who do not (National Telecommunications and Information Administration, 1999). As the literature suggests, social inequalities have also resulted in disparities in the equipment, autonomy, skills, support, and purposes of internet usage (DiMaggio et al., 2004). This phenomenon leads to an unequal opportunity, especially for the low income, less educated, and minority individuals to reap the benefits of the internet the same way that the privileged individuals can and do (Harris et al., 2017; Van Deursen \& van Dijk, 2019). Taking those into account, both social inequalities and digital divide may play an important role in shaping parents' attitudes toward LFH. It would be understandable for those who are in a disadvantaged position to develop more negative attitudes given the challenges they are facing.

Meanwhile, another research has shown direct relationships between digital divide and education (Pratama, 2017a). In this respect, countries with a higher participation rate in post-elementary education tend to have a higher ICT utilization rate in terms of internet users, broadband subscriptions, mobile subscriptions, and the number of secure Internet servers per capita. On the other hand, a higher ICT utilization is also associated with better educational outcomes of a country, especially in the number of articles published in scientific journals. In the past few years where access to ICT in general and Internet in particular have climbed worldwide, the focus has also shifted from the gap in access to ICT devices, to gap in infrastructures such as reliable and affordable internet coverage (Brandtzæg et al., 2011; Buys et al., 2009), to another gap in ICT skills and digital literacy (Gonzales, 2016; Van Deursen, 2017; Van Deursen \& van Dijk, 2019). Regardless of the current state, the digital divide is dynamic instead of static and permanent. Given the right treatment or intervention, it is possible to bridge and narrow the gap, both in access and in use (Van Dijk, 2017; Huxhold et al., 2020). In the LFH context, narrowing the digital divide might have the potential to help reduce those with negative attitudes toward the policy since doing so would make them digitally literate and believe in ICT as they benefit more from it.

\section{Research Objectives}

We conducted this study with two aims in mind. First, to explore parents' attitudes toward the LFH policy amid the COVID-19 pandemic in order to map their disposition toward the policy. Second, to investigate factors associated with such disposition to help understand why parents were classified under different categories. In doing so, this study tries to answer the following research questions, "To what extent do parents' attitudes toward the LFH policy vary?", "Is there any particular group of parents that warrants special attention?", and "What demographic factors characterize the likelihood of a parent to be in one group over another?". Considering that the LFH policy in Indonesia could be extended for a much longer period, getting an early-stage evaluation could help set a path to a make-or-break decision regarding the LFH policy. Furthermore, such categories will help the government, educators, and other stakeholders make proper interventions and avoid a one-fit-all approach.

\section{Methods}

\section{Participants and Procedure}

We distributed an online survey through social media (e.g., WhatsApp, Facebook, Twitter) in the first half of May 2020, around eight weeks after the LFH policy was 
announced by the Indonesian minister of education. A total of 261 participants (72\% females) who are a parent of at least one K-12 student in their households participated in the study after providing their informed consent. They came from 16 different provinces out of 34 available provinces in Indonesia and ranged from 24 to 60 years of age $(M=$ $38.63, S D=7.10$ ). More detailed information regarding the participants' demographics can be found in the group characteristics under the results section.

The questionnaire was delivered in Bahasa Indonesia, which is the national language of Indonesia. It specifically asked the participants as an individual, not as a couple. Thus, such answers arguably reflected the attitudes of the individual parent who filled out the questionnaire. These answers might also but not necessarily reflect their partner's attitudes. After carefully reviewing the responses, we concluded that none of the participants were either parents of the same children or partners within the same household.

\section{Measures}

\section{Sociodemographic Information}

We asked participants to report their monthly household income prior to COVID-19 pandemic, their and their partner's work from home status, their and their partner's educational attainment, their children's age/education level, and their ownership of personal computer (PC) and mobile devices at home. In the case of a single parent household, an appropriate option was available for each of the applicable questions.

\section{Learning Activities}

We provided the participants with seven common learning activities in addition to "other" as an open-ended option. We asked them to pick any learning activities their children had experienced within the first eight weeks of LFH.

\section{Attitudes toward LFH}

We developed a questionnaire consisting of seven items to measure parents' attitudes toward the LFH policy in terms of its usefulness and demandingness from their own perspective in a five-point Likert rating scale. The items were generated based on our observations on the ongoing conversations among parents on social media in Indonesia so that they arguably captured their current concerns, which were unique to the pandemic situation within the Indonesian context. We used the top-two box score approach to convert the answers into binary items as we are more concerned with their agreements with each item in the questionnaire, an approach commonly used in past studies to evaluate attitudes toward public policy and service (e.g., Gault et al., 2018; Kotnik et al., 2020; Popovic et al., 2013). Reliability of the measurement items was measured by Cronbach's alpha that yielded a score of 0.75 , which is considered acceptable in exploratory research such as in this study (Cortina, 1993; Taber, 2018). We used factor analysis to test for validity and internal consistency and to confirm that each measurement item belongs to the respective latent construct.

\section{Data Analysis}

In this study, we employed latent class analysis (LCA) to identify unmeasured class or group membership among parents using categorical observed variables (i.e., their answer to the measurement items in the survey). We used the gsem function in STATA 15 with logit model to predict the probability of each parent belonging to one of mutually exclusive latent classes. We used several goodness-of-fit indices, such as Likelihood-ratio $\left(\mathrm{G}^{2}\right)$ test to evaluate the model fit and Bayesian information criterion (BIC) to compare several different models when deciding how many latent classes to retain.

Once all classes and their members were identified, we employed multinomial logistic regression analysis to predict the likelihood of a parent to be in one group over another based on their demographic factors. Relative risks were used to compare the ratio of probability of a parent to be in one group instead of the reference group. In other words, this statistical analysis is used to see if there are some significant demographic differences across different groups of parents based on their attitudes toward LFH.

\section{Results}

\section{Reported Learning Activities}

Table 1 summarizes the top seven learning activities within the first eight weeks of LFH according to the parents. Despite embracing an online learning approach, the most reported activity was still traditional homework where students need to do offline prior to submitting their work to their teachers using any online methods. It was followed closely by asynchronous communication through instant messenger applications (e.g., WhatsApp group chats) at the second place, as well as online assessment in the forms of quizzes, exercises, and exams at the third place.

Watching educational videos, be it from the free-to-air school at home program broadcast by the national TV station or from an online source like YouTube ranked the fourth and fifth place, respectively. Tied at the bottom place are synchronous communication through teleconferencing apps like Zoom or Google Meet and navigating Learning 
Table 1 Summary of LFH activities reported by parents

\begin{tabular}{lll}
\hline Rank & Type of Activity & $N(\%)$ \\
\hline $\mathbf{1}$ & $\begin{array}{l}\text { Traditional homework } \\
\text { Offline homework to be submitted online } \\
\text { Text-based communication } \\
\text { Discussion through instant messenger, mainly } \\
\text { WhatsApp groups }\end{array}$ & $152(58 \%)$ \\
$\mathbf{3}$ & $\begin{array}{l}\text { Online assessment } \\
\text { Online quizzes, exercises, and exams }\end{array}$ & $146(56 \%)$ \\
$\mathbf{5}$ & $\begin{array}{l}\text { Free-to-air LFH program } \\
\text { Broadcast by the national TV station on school } \\
\text { days }\end{array}$ & $139(53 \%)$ \\
Online videos \\
Educational videos, including from YouTube \\
Video-based synchronous communication \\
Teleconference through Zoom or Google Meet \\
Learning Management System \\
Utilizing Moodle, Google Classroom, or any \\
other learning management system
\end{tabular}

Table 2 Summary of measurement items

\begin{tabular}{lr}
\hline Item & $N(\%)$ \\
\hline Usefulness & \\
1. LFH has been effective. & $41(16 \%)$ \\
2. LFH is the best option amid the pandemic. & $178(68 \%)$ \\
Demandingness & \\
1. LFH is expensive. & $111(43 \%)$ \\
2. LFH has been hard for parents. & $91(35 \%)$ \\
3. LFH forces parents to learn more. & $123(47 \%)$ \\
4. LFH means more work for parents. & $120(46 \%)$ \\
5. LFH is not ideal for parents' current conditions. & $85(33 \%)$ \\
\hline
\end{tabular}

Management Systems such as Moodle and Google Classroom. Only less than $1 \%$ of participants reported any other learning activities.

\section{Disengaged, Positive, and Negative Attitudes}

The summary of the survey responses is presented in Table 2 . It denotes the percentage of parents in agreement with each respected survey statement.

Following the answers to the measurement items about usefulness and demandingness of LFH from the perspective of parents, the LCA yielded three mutually exclusive groups, which we labeled as disengaged $(23 \%)$, positive $(41 \%)$, and negative (36\%). This identification was based on the distinct patterns of the compound attitudes toward the LFH policy. As explained in the method section, we employed multiple parameters to evaluate this categorization. As can be seen in Table 3, the 3-class model offered the best fit to the data.
Table 3 Goodness of fit of LCA models

\begin{tabular}{lllllll}
\hline Model & $\mathrm{G}^{2}$ & $d f\left(\mathrm{G}^{2}\right)$ & $p$ & LL Model & BIC & $d f(\mathrm{BIC})$ \\
\hline 1-Class & 553.14 & 120 & $<0.001$ & -1148.71 & 2336.38 & 7 \\
2-Class & 178.39 & 112 & $<0.001$ & -961.34 & 2006.14 & 15 \\
3-Class & 100.35 & 104 & 0.583 & -922.32 & 1972.62 & 23 \\
4-Class & 79.17 & 96 & 0.893 & -911.72 & 1995.95 & 31 \\
\hline
\end{tabular}

Figure 1 illustrates the distribution of parents in each group who have an agreement with each measurement item in the survey. The disengaged parents scored low in virtually all items. As can be seen, parents in the disengaged group had the lowest agreement level for all measurement items. In fact, some statements had not a single parent from this group in agreement with them. In terms of usefulness, the majority of parents who agreed with survey statements came from the positive group. On the other hand, most parents who agreed with the demandingness items came from the negative group.

The demographic information of parents for each group is presented in Table 4. More attention should be paid on monthly household income, children's age, and device ownership at home in which the discrepancies between groups were considerably high. As can be seen, most parents in the disengaged group had a low monthly income background, contrary to the other two groups. Meanwhile, most parents in the negative group had young children (K$6^{\text {th }}$ graders) at home unlike the other two groups. In terms of device ownership, parents in the positive group were the one with the highest percentage of having a PC or mobile devices at home compared to the other two groups.

\section{Factors Associated with Groups}

We performed a multinomial logistic regression to investigate factors associated with likelihoods for parents to be in a particular group. Even though the demographic information might have given some hints, such analysis would validate if those hints were statistically significant or not. In doing so, we used the disengaged group as the baseline. Thus, the results as shown in Table 5 should be interpreted as the likelihood of a parent to be in either positive or negative groups vis-a-vis the likelihood to be in the disengaged group.

The multinomial logistic regression model indicated a significant association between demographic factors and the three group memberships $\left(\chi^{2}(18)=74.94, p<0.001\right)$. As the results suggest, for each additional year of age, parents become less likely to be either in the positive $(R R=0.93$, $\mathrm{SE}=0.03, p=0.015)$ or negative group $(\mathrm{RR}=0.94, \mathrm{SE}=$ $0.03, p=0.040$ ). Likewise, coming from a low-income household also decreases the likelihood of parents to be either in the positive $(\mathrm{RR}=0.37, \mathrm{SE}=0.18, p=0.044)$ or 
Fig. 1 Three groups of parents based on latent class analysis on their attitudes toward LFH

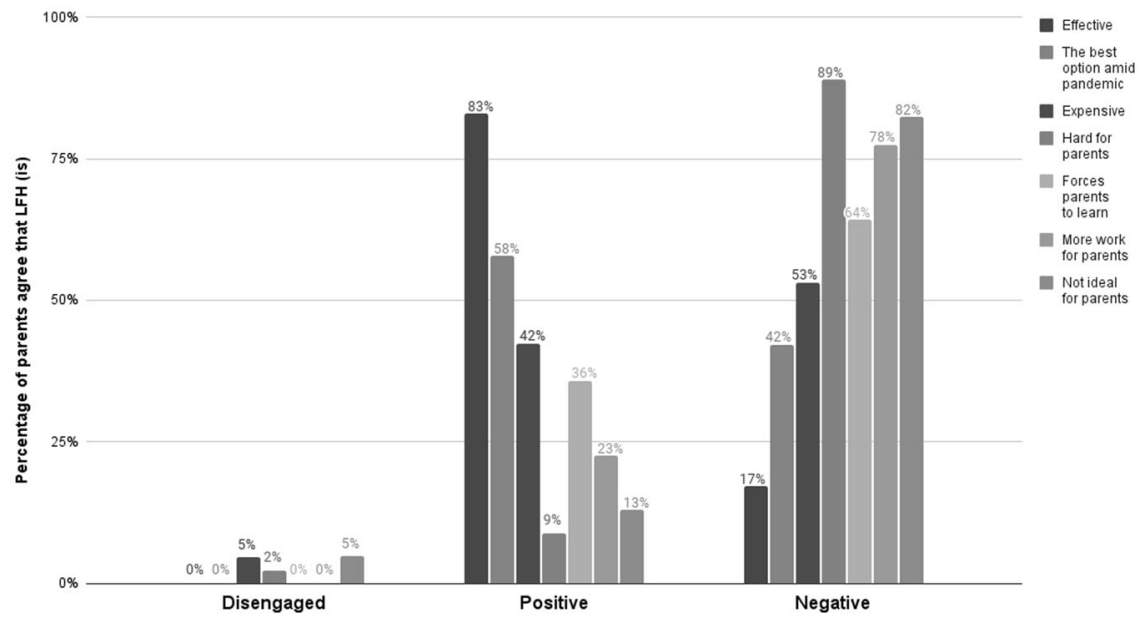

negative group $(\mathrm{RR}=0.23, \mathrm{SE}=0.13, p=0.007)$. In other words, parents in the disengaged group tend to be older and from a low-income household compared to the other two groups. Female parents are less likely to be in the negative group $(\mathrm{RR}=0.36, \mathrm{SE}=0.16, p=0.023)$, but not in the positive group. On the contrary, parents who have young children (K-6 ${ }^{\text {th }}$ grades) at home are more likely to be in the negative group $(\mathrm{RR}=4.54, \mathrm{SE}=3.28, p=0.036)$, but not in the positive group. Furthermore, having a PC (i.e., a desktop or a laptop) at home increases the likelihood for parents to be in the positive group $(\mathrm{RR}=4.15, \mathrm{SE}=1.93$, $p=0.002$ ), but not in the negative group. Interestingly, a similar association was not found in the case of mobile device (i.e., a smartphone or a tablet) ownership. Finally, we could not find any significant associations between parents' education or work from home (WFH) status and being in any group, either.

\section{Discussion}

The results have revealed three distinct groups of parents with unique compounds of attitudes toward the LFH policy: disengaged, positive, and negative. Parents in disengaged groups show indifferent attitudes toward the LFH as a policy regardless of its implementation. Parents in this category do not consider LFH effective, nor do they consider it as the best option for their children's education amid the pandemic. At the same time, they are also the only group who do not see LFH as a burden whatsoever. It could be the case that they are preoccupied with some more important things, such as foods and other necessities. It makes more sense especially since parents from the lowincome households with monthly income of less than IDR 3 million (approximately USD 200) are more likely to be in this group than in any other group. More specifically, they make up $58 \%$ of all parents in the disengaged group. As for parents who are not from the low-income households yet belong to the disengaged group, 17 of 25 have monthly income of less than IDR 10 million (approximately USD 667), meaning they still belong to the middle class instead of the upper class, indicating a similar problem albeit at a different magnitude is still at play. While the explanation above may hold water for the vast majority, more information is required for the small number of parents with monthly income between IDR 10 to 50 million yet belong to the disengaged group. Something that, at this point, we do not yet have any specific explanation as to why they see LFH as something that is neither useful nor demanding amid the pandemic. It is possible that they simply do not care enough about it, but such a reason is difficult to accept without further evidence.

In contrast, parents in the other two groups share quite the opposite views on LFH in terms of its usefulness and demandingness. Parents with negative attitudes consider LFH as very demanding, i.e., more expensive, harder for them, forces them to learn more, gives them extra work, and not ideal overall. While $42 \%$ of them admit LFH is indeed the best option amid the pandemic, parents in this group seem to perceive this policy as too demanding and less effective. The fact most parents in this group have young children $\left(\mathrm{K}-6^{\text {th }}\right.$ graders) instead of teenagers $\left(7^{\text {th }}-12^{\text {th }}\right.$ graders) at home may help explain why the negative attitude. As a previous study suggests, online learning with preschoolers and younger children requires more adult involvement that is geared more toward scaffolding and guided interaction as opposed to reactive supervision (Plowman and Stephen, 2005). Thus, the parents are forced to make extra efforts. In addition, it is worth noting that parents in this group seem to perceive this extra effort differently. As the result shows, being a father (as opposed to a mother) increases the likelihood of a parent to be in the group with 
Table 4 Demographic information of the three groups of parents based on their attitudes toward LFH

\begin{tabular}{|c|c|c|c|}
\hline Variable of Interest & $\begin{array}{l}\text { Group 1: } \\
\text { Disengaged } \\
N(\%)\end{array}$ & $\begin{array}{l}\text { Group 2: } \\
\text { Positive } \\
N(\%)\end{array}$ & $\begin{array}{l}\text { Group 3: } \\
\text { Negative } \\
N(\%)\end{array}$ \\
\hline \multicolumn{4}{|l|}{ Sex } \\
\hline 1. Male & $13(18 \%)$ & $27(37 \%)$ & $33(45 \%)$ \\
\hline 2. Female & $47(25 \%)$ & $81(43 \%)$ & $60(32 \%)$ \\
\hline \multicolumn{4}{|l|}{ Age } \\
\hline 1. 24-30 years old & $7(24 \%)$ & $13(45 \%)$ & $9(31 \%)$ \\
\hline 2. $31-40$ years old & $27(18 \%)$ & $63(43 \%)$ & $58(39 \%)$ \\
\hline 3. $41-50$ years old & $19(28 \%)$ & $29(42 \%)$ & $21(30 \%)$ \\
\hline 4. 51-60 years old & $7(47 \%)$ & $3(20 \%)$ & $5(33 \%)$ \\
\hline \multicolumn{4}{|l|}{ Monthly Income } \\
\hline $\begin{array}{l}\text { 1. Low-income } \\
\text { household }^{*}\end{array}$ & $35(47 \%)$ & $24(32 \%)$ & $15(20 \%)$ \\
\hline $\begin{array}{l}\text { 2. Middle to High } \\
\text { income household }\end{array}$ & $25(13 \%)$ & $84(45 \%)$ & $78(42 \%)$ \\
\hline \multicolumn{4}{|l|}{ Work from Home } \\
\hline 1. At least one parent & $29(21 \%)$ & $59(44 \%)$ & $47(35 \%)$ \\
\hline 2. None of the parents & $31(25 \%)$ & $49(39 \%)$ & $46(37 \%)$ \\
\hline \multicolumn{4}{|l|}{ Educational Attainment } \\
\hline 1. Postgraduate degree & $14(14 \%)$ & $44(44 \%)$ & $42(42 \%)$ \\
\hline 2. Undergraduate degree & $21(19 \%)$ & $45(41 \%)$ & $43(39 \%)$ \\
\hline 3. No college & $25(48 \%)$ & $19(37 \%)$ & $8(15 \%)$ \\
\hline \multicolumn{4}{|l|}{ Children's Age } \\
\hline $\begin{array}{l}\text { 1. At least one } \mathrm{K}-6^{\text {th }} \\
\text { graders }\end{array}$ & $47(21 \%)$ & $93(41 \%)$ & $89(39 \%)$ \\
\hline 2. $7^{\text {th }}-12^{\text {th }}$ graders only & $13(41 \%)$ & $15(47 \%)$ & $4(13 \%)$ \\
\hline \multicolumn{4}{|l|}{ Device Ownership at Home } \\
\hline 1. PC (desktop/laptop) & $27(15 \%)$ & $88(48 \%)$ & $69(38 \%)$ \\
\hline $\begin{array}{l}\text { 2. Neither a desktop nor } \\
\text { a laptop }\end{array}$ & $33(43 \%)$ & $20(26 \%)$ & $24(31 \%)$ \\
\hline $\begin{array}{l}\text { 3. Mobile (smartphone/ } \\
\text { tablet) }\end{array}$ & $46(20 \%)$ & $98(43 \%)$ & $83(37 \%)$ \\
\hline $\begin{array}{l}\text { 4. Neither a smartphone } \\
\text { nor a tablet }\end{array}$ & $14(41 \%)$ & $10(29 \%)$ & $10(29 \%)$ \\
\hline Total & $60(23 \%)$ & $108(41 \%)$ & $93(36 \%)$ \\
\hline
\end{tabular}

Note. Total may not add up to $100 \%$ due to roundings; ${ }^{*}$ Less than IDR 3 million (USD 200)

negative attitudes than in any other group. Linking this finding with patriarchal culture deeply rooted in Indonesia (Murtiningsih et al., 2017), it can be the case that fathers, who traditionally have less roles in domestic work including raising children, hesitate to take a part and therefore find it as an additional burden, hence seeing LFH as too demanding for them. Further research is needed to confirm this proposed explanation.

The last group of parents share positive attitudes toward LFH. They see LFH not only as the best option amid the pandemic, but also has been, insofar effective. Parents in this
Table 5 Multinomial logistic regression estimates

\begin{tabular}{|c|c|c|c|c|c|c|}
\hline \multirow[t]{2}{*}{ Variable of Interest } & \multicolumn{3}{|c|}{ Group 2: Positive } & \multicolumn{3}{|c|}{ Group 3: Negative } \\
\hline & $\mathrm{RR}$ & $S E$ & $p$ & RR & $S E$ & $p$ \\
\hline \multicolumn{7}{|l|}{ Sex } \\
\hline (Female) & 0.74 & 0.32 & 0.485 & 0.36 & 0.16 & $\mathbf{0 . 0 2 3} *$ \\
\hline \multicolumn{7}{|l|}{ Age } \\
\hline (Years old) & 0.93 & $\mathbf{0 . 0 3}$ & $0.015^{*}$ & 0.94 & $\mathbf{0 . 0 3}$ & $0.040 *$ \\
\hline \multicolumn{7}{|l|}{ Monthly Income } \\
\hline $\begin{array}{l}\text { (Low-income } \\
\text { household) }\end{array}$ & 0.37 & 0.18 & $0.044 *$ & 0.23 & 0.13 & $0.007 * *$ \\
\hline \multicolumn{7}{|l|}{ Work from Home } \\
\hline $\begin{array}{l}\text { (At least one } \\
\text { parent) }\end{array}$ & 0.90 & 0.34 & 0.788 & 0.62 & 0.25 & 0.233 \\
\hline \multicolumn{7}{|c|}{ Educational Attainment } \\
\hline $\begin{array}{l}\text { (Postgraduate } \\
\text { degree) }\end{array}$ & 1.26 & 0.58 & 0.618 & 1.54 & 0.74 & 0.364 \\
\hline (No college) & 1.12 & 0.60 & 0.837 & 0.36 & 0.18 & 0.101 \\
\hline \multicolumn{7}{|l|}{ Children's Age } \\
\hline $\begin{array}{l}\left(\mathrm{K}-6^{\text {th }} \text { graders }\right. \\
\text { at home })\end{array}$ & 1.07 & 0.61 & 0.901 & 4.54 & 3.28 & $0.036 *$ \\
\hline \multicolumn{7}{|c|}{ Device Ownership at Home } \\
\hline $\begin{array}{l}\text { (PC - desktop/ } \\
\text { laptop) }\end{array}$ & 4.15 & 1.93 & $0.002 * *$ & 1.46 & 0.69 & 0.429 \\
\hline $\begin{array}{l}\text { (Mobile - } \\
\text { smartphone/ } \\
\text { tablet) }\end{array}$ & 2.08 & 1.11 & 0.172 & 0.99 & 0.56 & 0.988 \\
\hline Constant & 9.69 & 15.27 & 0.150 & 17.33 & 29.84 & 0.098 \\
\hline Model $\chi^{2}$ & \multicolumn{6}{|c|}{$74.94 * * *$} \\
\hline Pseudo $\mathrm{R}^{2}$ & \multicolumn{6}{|c|}{0.134} \\
\hline df & \multicolumn{6}{|l|}{18} \\
\hline Observation & \multicolumn{6}{|l|}{261} \\
\hline
\end{tabular}

Note. Relative risk $(R R)$; standard error $(S E)$; Group 1: Disengaged is used as the baseline; ${ }^{*} p<0.05$. ${ }^{* *} p<0.01 * * * p<0.001$

group do not see LFH as too demanding either. An interesting significant factor found in this positive group but not in the other two groups is PC (i.e. desktop/laptop) ownership. The significance of $\mathrm{PC}$ ownership at home further emphasizes a deeper problem regarding digital divide among households, even when letting key demographic factors such as income aside. As past research found, providing access to a PC and internet connectivity to low-income households with schoolage children as was done by the UK government between 2008 and 2010 successfully increased parental engagement with their children's learning (Jewitt \& Parashar, 2011). This study further emphasizes that PC ownership at home is the key to the parents' positive attitudes toward the LFH policy. In that sense, PC ownership at home is a good indicator of digital literacy of a household. Thus, it makes more sense that parents in this group are more digitally literate compared to the other two groups, hence they do not find LFH too demanding. In fact, parents in this category are the only one who think that 
the policy is somewhat effective. Should parents in this category have to help their children do some distance learning, not only do they have the necessary devices and infrastructures, but also, they tend to be digitally literate to do so. However, since the level of digital literacy of the parents was not measured in this study, this explanation should be digested with caution as alternative explanations may hold.

Meanwhile, mobile device ownership is less adequate to tell whether a household or a person is digitally literate or not. In the case of the smartphone, it is the technological convergence of personal computing device and personal communication device, making it the most popular digital device to own, whereas tablet ownership is rare and is usually limited to people from a high-income household (Pratama, 2017b; Pratama \& Scarlatos, 2020). Nevertheless, it does not mean that mobile devices are less influential for learning than PCs are. As suggested by a previous study, the prospects of the mobile internet (i.e., internet access from a mobile device) for narrowing the digital divide in developing countries should not be underrated (Puspitasari \& Ishii, 2016). Even more so in Indonesia where most of the internet traffic comes from mobile internet (ICT Statistics Sub Directorate, 2019) due to the lack of and uneven access to fixed broadband internet, something that is more common and more affordable than mobile internet connection in many developed countries. It all comes down to the type of learning activities involved and the learning strategies employed by the educators. As suggested by another study with the same Indonesian students' population, active and collaborative learning strategies such as searching for literature, synchronous/asynchronous text-based communication, and collaboration work are much more preferred to be done by students on a mobile device than passive learning strategies such as reading materials, online quizzes and assessments, or watching educational video (Pratama \& Scarlatos, 2020). Considering the types of learning activities involved in this study as reported by the parents were still heavy on the passive learning strategies, it is likely to be one of the reasons why mobile device ownership does not produce the same effect as PC ownership does in promoting more positive parents' attitudes toward LFH.

\section{Implications}

As teachers are no longer able to provide the same level of guidance, supervision, and monitoring the way they do in class settings, parents involvement is an important key to make sure that the LFH policy succeeds. Ideally, all parents should be in the group with positive attitudes. Even when it is practically impossible to get all parents to be in this group, increasing the number of parents sharing positive attitudes needs to be a priority. As the positive group seems to be already self-supported (i.e., they tend to have the necessary infrastructure to facilitate their children do LFH), it means that the government, schools, and teachers may pay less attention to them and shift their focus to the other two groups with a goal of having them to change their attitudes to a more positive direction in mind.

In doing so, different groups of parents require different treatments and nudges. Disengaged groups may require direct help with their very basic necessities. Once those are met, then they can start thinking about other things including their children's education. Also, though it is beyond the policy context, teachers may also consider learning activities that not only benefit the students but also their parents such as teaching how technology helps people survive the pandemic. The other group with negative attitudes, on the other hand, may not need the same direct help as parents in the disengaged group. Considering they are the only group who see the policy as too demanding, changing the learning method may be of help. For instance, teachers can develop learning plans based on methods that have existed for decades, in which parents might have experienced them back when they were students themselves. Doing so will arguably reduce the needs for parents, particularly those with negative attitudes, to learn a lot of new learning materials and techniques by themselves.

Nevertheless, that kind of solution seems to be a quick temporary fix. A more comprehensive approach in facilitating these two groups is necessary should they be expected to be more supportive to the LFH policy. For example, reflecting upon another case of educational technology and policy in Indonesia, the free electronic textbook program introduced by the government more than a decade ago has shown to help nudge students to have more positive attitudes toward ebook in general (Pratama \& Firmansyah, 2020). Considering the finding suggests that digital divide among parents does play such an important role in this matter, addressing that problem with policies that specifically aim for helping vulnerable groups of parents (e.g., low income, senior citizens) narrow the gaps might give a greater impact in the long run.

\section{Limitations and Future Work}

While this study highlights the existence of gaps between groups of parents in dealing with the LFH policy amid COVID-19 pandemic and indicates some important factors at play, there are some limitations in this study. To be more representative of the overall student's parents' population in the entire country, the sample size is relatively small and may not have included all vulnerable populations. For example, those living in remote areas where internet connection is still deemed as a luxury instead of a basic necessity in this information age. That said, this study could definitely benefit more from a larger and more diverse 
sample. Also, a more comprehensive analysis focusing on location and student's education level could complement this study in order to see the bigger picture on the matter. Considering that LFH has been extended in 2021, there is enough time to replicate the survey for the future work, not only with a better sample, but also with some improvement in the methodology, mainly on the development of new scales based on the literature in addition to the findings from this study. Another route to go is by incorporating some qualitative analysis in the form of in-depth interviews with each group representative to provide a better and deeper understanding on the matter.

Furthermore, a parents' perspective is only one side of the story, there are at least two other sides to cover, one from the students' perspective and another one from the teachers' perspective. After all, students are the main protagonists of LFH, and they are the ones whose education is affected and disrupted by the pandemic. Meanwhile, not all teachers are prepared for teaching in an online learning environment. Understanding the challenges that they are facing is necessary. Finally, the LFH policy evaluated in this study depends a lot on the type of learning activities involved. Should the learning activities change dramatically, the resulting experience might also change and thus, the attitudes toward LFH could be affected, too.

Funding This study was self-funded by the authors.

\section{Compliance with ethical standards}

Conflict of interest The authors declare no competing interests.

Informed consent Informed consent was obtained from all individual participants included in the study.

Publisher's note Springer Nature remains neutral with regard to jurisdictional claims in published maps and institutional affiliations.

\section{References}

Azmi. (2021, January 11). Surat edaran nomor 1/SE/2021 tentang persiapan pembelajaran tatap muka (PTM) semester genap tahun pelajaran 2020/2021. Dinas Pendidikan. https://disdik.jakarta.go.id/a rticle/1537-surat-edaran-nomor-1se2021-tentang-persiapan-pembela jaran-tatap-muka-ptm-semester-genap-tahun-pelajaran-20202021/.

Brandtzæg, P. B., Heim, J., \& Karahasanović, A. (2011). Understanding the new digital divide-A typology of Internet users in Europe. International Journal of Human-Computer Studies, 69 (3), 123-138. https://doi.org/10.1016/j.ijhcs.2010.11.004.

Brown, N., te Riele, K., Shelley, B., \& Woodroffe, J. (2020). Learning at home during COVID-19: Effects on vulnerable young Australians. Peter Underwood Centre for Educational Attainment, University of Tasmania. https://www.dese.gov.au/system/files/ doc/other/learning_at_home_during_covid_30042020.pdf.

Buys, P., Dasgupta, S., Thomas, T. S., \& Wheeler, D. (2009). Determinants of a digital divide in Sub-Saharan Africa: A spatial econometric analysis of cell phone coverage. World Development, 37(9), 1494-1505. https://doi.org/10.1016/j.worlddev.2009.01.011.

CNN Indonesia (2020, April 24). Kemendikbud buat skenario belajar di rumah sampai akhir 2020. https://www.cnnindonesia.com/na sional/20200424114337-20-496861/kemendikbud-buat-skenariobelajar-di-rumah-sampai-akhir-2020.

Clark, L. S., Demont-Heinrich, C., \& Webber, S. (2005). Parents, ICTs, and children's prospects for success: Interviews along the digital "Access Rainbow". Critical Studies in Media Communication, 22 (5), 409-426. https://doi.org/10.1080/07393180500342985.

Cortina, J. M. (1993). What is coefficient alpha? An examination of theory and applications. Journal of Applied Psychology, 78(1), 98 https://doi.org/10.1037/0021-9010.78.1.98.

Cross, C. (2020, June 16). Working and learning from home during the COVID-19 outbreak. American Academy of Pediatrics. https://www.healthychildren.org/English/health-issues/ conditions/COVID-19/Pages/Working-and-Learning-fromHome-COVID-19.aspx.

DiMaggio, P., Hargittai, E., Celeste, C., \& Shafer, S. (2004). Digital inequality: From unequal access to differentiated use. In K. Neckerman (ed.), Social inequality (pp. 355-400). Russell Sage Foundation.

Eccles, J. S., \& Harold, R. D. (1993). Parent-school involvement during the early adolescent years. Teachers College Record, 94 (3), 568-58.

Evangelisti, S. (2013). Learning from home: discourses on education and domestic visual culture in early modern Italy. History, 98 (333), 663-679. https://doi.org/10.1111/1468-229X.12030.

Fishel, M., \& Ramirez, L. (2005). Evidence-based parent involvement interventions with school-aged children. School Psychology Quarterly, 20(4), 371 https://doi.org/10.1521/scpq.2005.20.4.371.

Gault, J., Leach, E., Duey, M., \& Benzing, T. (2018). Enhancing the value of professional experience in undergraduate education: Implications for academic and career counseling. Journal of Employment Counseling, 55(4), 144-154. https://doi.org/10. 1002/joec.12094.

Gonzales, A. (2016). The contemporary US digital divide: from initial access to technology maintenance. Information, Communication \& Society, 19(2), 234-248. https://doi.org/10.1080/1369118X. 2015.1050438.

Gross, D., Bettencourt, A. F., Taylor, K., Francis, L., Bower, K., \& Singleton, D. L. (2020). What is parent engagement in early learning? Depends who you ask. Journal of Child and Family Studies, 29 (3), 747-760. https://doi.org/10.1007/s10826-019-01680-6.

Harris, C., Straker, L., \& Pollock, C. (2017). A socioeconomic related'digital divide'exists in how, not if, young people use computers. PLoS ONE, 12(3), e0175011 https://doi.org/10.1371/ journal.pone.0175011.

Huxhold, O., Hees, E., \& Webster, N. J. (2020). Toward bridging the grey digital divide: Changes in internet access and its predictors from 2002 to 2014 in Germany. European Journal of Ageing, 17, 271-280. https://doi.org/10.1007/s10433-020-00552-z.

ICT Statistics Sub Directorate. (2019). Indeks Pembangunan Teknologi, Informasi, dan Komunikasi (ICT Development Index) 2018. BPS-Statistics Indonesia. https://www.bps.go.id/publication/ 2019/11/29/0328ba9a85b461816e917291/indeks-pembangunanteknologi-informasi-dan-komunikasi-2018.html.

Jewitt, C., \& Parashar, U. (2011). Technology and learning at home: findings from the evaluation of the home access programme pilot. Journal of Computer Assisted Learning, 27(4), 303-313. https:// doi.org/10.1111/j.1365-2729.2011.00434.x.

Kellaghan, T., Sloane, K., Alvarez, B., \& Bloom, B. S. (1993). The home environment and school learning: Promoting parental involvement in the education of children. Jossey-Bass. 
Kementerian Pendidikan dan Kebudayaan (2020a). Mendikbud terbitkan SE tentang pelaksanaan pendidikan dalam masa darurat COVID-19. https://www.kemdikbud.go.id/main/blog/2020/03/ mendikbud-terbitkan-se-tentang-pelaksanaan-pendidikan-dalammasa-darurat-covid 19.

Kementerian Pendidikan dan Kebudayaan (2020b). Kemendikbud hadirkan program tayangan "Belajar dari Rumah" di TVRI. https://www.kemdikbud.go.id/main/blog/2020/04/kemendikbudhadirkan-program-tayangan-belajar-dari-rumah-di-tvri.

Kementerian Pendidikan dan Kebudayaan (2020c). Kemendikbud terbitkan pedoman penyelenggaraan belajar dari rumah. https://www.kemdikbud.go.id/main/blog/2020/05/kemendikbudterbitkan-pedoman-penyelenggaraan-belajar-dari-rumah.

Knowles, J. G., Muchmore, J. A., \& Spaulding, H. W. (1994). Home education as an alternative to institutionalized education. The Educational Forum, 58(3), 238-243. https://doi.org/10.1080/ 00131729409335339.

Kotnik, Ž., Umek, L., Kovač, P., Stanimirović, D., \& Vintar, M. (2020). Analysis of the key factors for successful public policy implementation: a qualitative study in Slovenia. DANUBE: Law, Economics and Social Issues Review, 11(2), 113-140. https://doi. org/10.2478/danb-2020-0007.

Masters, G. N., Taylor-Guy, P., Fraillon, J., \& Chase, A. M. (2020). Ministerial briefing paper on evidence of the likely impact on educational outcomes of vulnerable children learning at home during COVID-19. Australian Government Department of Education, Skills and Employment. https://research.acer.edu.au/lea rning_processes/24/.

Murtiningsih, B. S. E., Advenita, M., \& Ikom, S. (2017). Representation of patriarchal culture in new media: A case study of news and advertisement on Tribunnews.com. Mediterranean Journal of Social Sciences, 8(3), 143-154. https://doi.org/10. 5901/mjss.2017.v8n3p143.

National Telecommunications and Information Administration. (1999). Falling through the net: Defining the digital divide. United States Department of Commerce. https://www.ntia.doc. gov/report/1999/falling-through-net-defining-digital-divide.

Nye, C., Turner, H., \& Schwartz, J. (2006). Approaches to parent involvement for improving the academic performance of elementary school age children. Campbell Systematic Reviews, 2(1), 1-49. https://doi.org/10.4073/csr.2006.4.

Office of Assistant to Deputy Cabinet Secretary for State Documents \& Translation. (2021, January 25). The Home Minister issues instruction to extend activity restrictions. Cabinet Secretariat of the Republic of Indonesia. https://setkab.go.id/en/home-ministerissues-instruction-to-extend-activity-restrictions/.

Pena, D. C. (2000). Parent involvement: influencing factors and implications. The Journal of Educational Research, 94(1), 42-54. https://doi.org/10.1080/00220670009598741.

Pezdek, K., Berry, T., \& Renno, P. A. (2002). Children's mathematics achievement: the role of parents' perceptions and their involvement in homework. Journal of Educational Psychology, 94(4), 771-777. https://doi.org/10.1037/0022-0663.94.4.771.

Plowman, L., \& Stephen, C. (2005). Children, play, and computers in pre-school education. British Journal of Educational Technology, 36(2), 145-157. https://doi.org/10.1111/j.1467-8535. 2005.00449.x.

Plowman, L., Stevenson, O., McPake, J., Stephen, C., \& Adey, C. (2011). Parents, pre-schoolers and learning with technology at home: some implications for policy. Journal of Computer Assisted Learning, 27(4), 361-371. https://doi.org/10.1111/j. 1365-2729.2011.00432.x.
Popovic, K., Smith, C., \& Hellebusch, S. J. (2013). Attitudes on the use of social media in healthcare communications. Journal of Communication in Healthcare, 6(1), 22-28. https://doi.org/10. 1179/1753807612Y.0000000029.

Pratama, A. R. (2017a). Cross-country analysis of ICT and education indicators: an exploratory study. In IOP conference series: Materials Science and Engineering, 185(1). IOP Publishing. https://doi.org/10.1088/1757-899X/185/1/012006.

Pratama, A. R. (2017b). Exploring Personal Computing Devices Ownership Among University Students in Indonesia. In International Conference on Social Implications of Computers in Developing Countries (pp. 835-841). Springer, Cham. https://doi. org/10.1007/978-3-319-59111-7_70.

Pratama, A. R., \& Firmansyah, F. M. (2020). How can governments nudge students to become ebook readers? Evidence from Indonesia. Digital Library Perspectives, 37(3), 1-13. https://doi.org/ 10.1108/DLP-07-2020-0066.

Pratama, A. R., \& Scarlatos, L. L. (2020). The roles of device ownership and infrastructure in promoting e-learning and m-learning in Indonesia. International Journal of Mobile and Blended Learning, 12(4), 1-16. https://doi.org/10.4018/IJMBL.2020100101.

Puspitasari, L., \& Ishii, K. (2016). Digital divides and mobile Internet in Indonesia: Impact of smartphones. Telematics and Informatics, 33(2), 472-483. https://doi.org/10.1016/j.tele.2015.11.001.

Putri, R. S., Purwanto, A., Pramono, R., Asbari, M., Wijayanti, L. M., \& Hyun, C. C. (2020). Impact of the COVID-19 pandemic on online home learning: an explorative study of primary schools in Indonesia. International Journal of Advanced Science and Technology, 29(5), 4809-4818.

Rasmitadila, R., Aliyyah, R. R., Rachmadtullah, R., Samsudin, A., Syaodih, E., Nurtanto, M., \& Tambunan, A. R. S. (2020). The perceptions of primary school teachers of online learning during the COVID-19 pandemic period: A case study in Indonesia. Journal of Ethnic and Cultural Studies, 7(2), 90-109. https://doi. org/10.29333/ejecs/388.

Sikirit, D. (2020, June 2). Learning from home during the COVID-19 pandemic. United Nations Children's Fund Indonesia. https://www.unicef.org/indonesia/coronavirus/stories/learninghome-during-covid-19-pandemic.

Taber, K. S. (2018). The use of Cronbach's alpha when developing and reporting research instruments in science education. Research in Science Education, 48(6), 1273-1296. https://doi.org/10.1007/ s11165-016-9602-2.

Topor, D. R., Keane, S. P., Shelton, T. L., \& Calkins, S. D. (2010). Parent involvement and student academic performance: a multiple mediational analysis. Journal of Prevention \& Intervention in the Community, 38(3), 183-197. https://doi.org/10.1080/ 10852352.2010 .486297$.

Van Deursen, A. J. (2017). Digital divide: Impact of media literacy. In P. Rösslerhe (ed.), International Encyclopedia of Media Effects. Wiley. https://doi.org/10.1002/9781118783764.wbieme0044.

Van Deursen, A. J., \& van Dijk, J. A. (2019). The first-level digital divide shifts from inequalities in physical access to inequalities in material access. New Media \& Society, 21(2), 354-375. https:// doi.org/10.1177/1461444818797082.

Van Dijk, J. A. (2017). Digital divide: impact of access. In P. Rösslerhe (ed.), International Encyclopedia of Media Effects. Wiley. https://doi.org/10.1002/9781118783764.wbieme0043.

Yulianti, K., Denessen, E., \& Droop, M. (2019). Indonesian parents' involvement in their children's education: A study in elementary schools in urban and rural Java, Indonesia. School Community Journal, 29(1), 253-278. 